\title{
Employment Structure of the Population in area Industry Village, East Ungaran Sub-district, Semarang Regency, Central Java Province, Indonesia
}

\author{
Puji Hardati ${ }^{1, *}$ Dewi Liesnoor Setyowati ${ }^{2}$, YYFR Sunardjan ${ }^{3,}$ Fenny Fridasari ${ }^{4,}$ \\ Julia Dwi Indriana ${ }^{5}$ \\ 1,2,3,4,5 Departement of Geography Faculty of Social Sciences Universitas Negeri Semarang \\ *Corresponding author.Email: puji.hardati@mail.unnes.ac.id
}

\begin{abstract}
Village development is very dynamic and significant with village funding grants, although not evenly distributed. This study aims to examine the characteristics of the villages, the condition and employment structure of the population in the area of industrial activity. The study population was villages at the area of industrial activity, and all villages became populations. The research variables are the characteristics of the region, the condition of the population and the employment structure of the villagers' work. Analysis of the data used is quantitative descriptive, percentage tables, and figures. The results showed the villages around the location of industrial activity characteristics varied, with dynamic population conditions. The dominant occupational structure of the population is in the non-agricultural sector, with employment in the manufacturing industry and service. The structure of employment in the service sector reached 68.51 percent occurring in one village around the industry.
\end{abstract}

Keywords: population dynamics, employment structure, non-agriculture, manufacturing industry, service sector.

\section{INTRODUCTION}

Development contains the aim of improving the welfare of the population. Global development goals called sustainable development goals have been formulated together to be comprehensive and universal, have 17 goals and 169 goals [1] [2]. The SDGs are expected to be able to accommodate development problems in all countries, and lead to the welfare of the population, which will end in 2030. All countries have development goals, and experience a pandemic at the end of 2019 and to various countries in early 2020 . Goals to 8 of the SDGs are promoting exclusive sustainable economic growth, productive and comprehensive employment opportunities and decent work for all [3].

The world's population is increasing, in 2019 the world population is 7,555 billion [4], and is expected to reach 10, 9 billion in 2100 [5], the population is unevenly distributed throughout the world, countries in the Asian Continent has a population of more than countries in the European Continent. Asia in 2019 has a population of 4,587 billion or 59.64 percent of the world's population. The total global working age population reaches 5.7 billion, of which, around 58.4 percent are employed and 172 million are unemployed, with a labor force participation rate of 61.4 percent [6]. It is estimated that during the pandemic, around 1.25 billion or around 38 percent of the global workforce experienced a reduction in working hours [7].

Indonesia is one of the countries in Asia which has a population of 235 million [8], in 2019 it became 268.4 million, and ranks 4th in the world population, after China, India, America, Indonesia [4]. The population in Indonesia is not evenly distributed in each region, on the island of Java has the highest population with the highest population density. The Javanese population is 57 percent of the Indonesian population [8]. Java Island with 5 big provinces, namely Banten Province, DKI Jakarta Province, Central Java Province, Special Region of Yogyakarta, and East Java Province. Central Java Province is one of the regions in Java with the second largest population after East Java province. The number of Indonesians employed is around 62,902,717, 
with a somewhat lame employment structure, working in the agricultural or primary sector 13.17 percent, in the secondary sector 32.58 percent, and in the service sector 54.25 percent [9].

In Central Java Province, the dominant employment structure of the population is the service sector, which is 44.32 percent, and the lowest is the population that works in the primary sector, which is only 11.80 percent [9]. In various regions, especially in developing countries, there has been a shift in the structure of business fields, in Indonesia the transformation of employment is still lagging behind [10]. The development of the industrial sector is expected to contribute to employment opportunities [11] [12]. What is the work structure of the population in villages close to industrial sites. This study aims to analyze the structure of work in villages around industrial locations. Industrial development is expected to absorb labor and reduce unemployment, excess labor in the agricultural sector is absorbed by the industrial sector and services that have higher productivity and wage rates [13]. The agricultural sector remains the leading and the industrial and service sectors become its supporters.

\section{THEORETICAL REVIEW}

Development is expected to improve the welfare of the population through its involvement in work and business accuracy. Each region is very varied, so that it has different characteristics, so analyzing the characteristics of the region is very useful to get to know an area and contribute to a plan.

\subsection{Industrial Area}

Industry is an activity of processing goods from raw materials or semi-finished goods into finished goods or goods of more value and are ready for use or for consumption. Industry is an overall form of economic activity that processes raw materials and / or utilizes industrial resources so as to produce goods that have added value or higher benefits, including industrial services [14].

Industries are generally located near raw materials or near markets that are expected to be industrial products. The establishment of industry in a village contributes to the characteristics of an area [15]. Industrial estate is a center for the processing of industrial activities which is equipped with infrastructure, facilities and other supporting facilities provided and managed by the company of the industrial estate [16]. An industrial estate is an area in which there is industrial activity and has various facilities needed by industry. Facilities needed by industry vary depending on the type of industry, some in the form of laboratory facilities, office buildings, financial facilities in the form of banks, social facilities and public facilities [17]. Industries located in rural areas have a broad meaning, in the sense of encouraging the process of industrialization and being able to be a driver of physical, social, economic and cultural transformation in rural development. Villages around the industrial location are becoming more developed and developing, and rural diversification is taking place as a whole [14].

\subsection{Employment Structure}

The work structure is the occupational structure of the population in a region. Job structure also called the main employment or main industry, is the field of activity of the work / business / company / office where someone works [9]. The work of each population in a region is very varied, dynamic and complex, always changes, according to the level of culture. The more advanced a civilization will change jobs, globally has occurred since the industrial revolution from 1.0 to 5.0. The construction of work groupings is carried out by the international industry classification standards, into 21 sections (A to U), and 99 devisions [18]. Indonesia classifies employment in 17 categories based on the 2015 Indonesian business standard (KBLI) based on the International Standard Classification (ISIC) revised 4.

The division of employment that has been classified based on ISIC classification, and KBLI, can be simplified into three, namely the primary sector or the agricultural sector, the industrial sector or the sekuder sector, and the service or service sector or the tertiary sector. The three groups in detail are the first primary sectors or agricultural sectors which include agriculture, forestry and fisheries. The two secondary sectors, which include the mining and quarrying sector, processing industry, electricity and gas procurement, water supply, waste management, waste and recycling, construction. Third is the tertiary sector, which includes wholesale and retail trade, transportation and warehousing, provision of accommodation and food / drink, information and communication, financial and insurance services, real estate, company services, government administration, defense, and compulsory social security, education services, health services, other services [9]. Fields of workplace activities can also be grouped into two, namely employment in the agricultural and non-agricultural sectors.

\section{RESEARCH METHODS}

This research was conducted in Ungaran Timur Regency, Regency, Semarang. The area is one of the industrial sites, with a variety of workers. Research emphasizes quantitative, with spatial analysis. 
The study population was villages in the District of East Ungaran, research 10 villages / villages. All villages are used as research objects, so they are research. The research variables are regional characteristics, population conditions, and the employment structure of the population.

The data used in this study are secondary data sourced from the Central Statistics Agency, the Regional Development Planning Agency, the Office of Manpower and Transmigration, and related agencies. Data analysis uses descriptive percentages, classifications, scoring, weighting, analysis and map interpretation. The results of the study are presented in tables and figures. In the analysis phase using the percentage of each indicator $(\mathrm{P})=(\mathrm{n}$ : M) $\times 100$. Classification based on the percentage value, made 3 classes, with the first $1 / 3$ class $1,1 / 3$ second class 2 , and the last $1 / 3$ class 3 . It is always mapped with ArcGis, and analyzed and interpreted.

\section{RESULTS AND DISCUSSION 4.1. Regional Characteristics of East Ungaran Sub-District}

Ueast Ungaran Sub-District is one of the 19 districts in Semarang Regency, Central Java Province. Its location is in the eastern part of the region, and is bordered by Demak Regency and Seamrang City. The capital of the Eastern District is in the Village of Kalongan. The area has high accessibility, can be reached from various directions, namely from the City of Semarang, Demak Regency, and surrounding subdistricts. Even with the condition of village roads and district roads that are paved with no public transportation. The average distance to various villages in the sub-district is an average of 5.2 kilometers, and the distance to the Semarang Regency office is around 5.5 kilometers. The morphology of the region in general is relatively flat undulating, with an average altitude of 294 meters above sea level (mdpl), with the highest location of $399 \mathrm{mdpl}$ in Beji Village and the lowest of 80 masl in Mluweh Village.

In East Ungaran sub district, it has 17 industries, its location is not spread in all villages, but only in a few villages. The industry is located in Gedanganak Village, Susukan Village, Leyangan Village, Kalirejo Village, and Beji Village. In Gedanganak Village, there are 3 large and medium industries, which are able to absorb tens of thousands of workers, who come from various surrounding areas. The composition of the workforce, with male and female sex, but predominantly female. Most industries are the textile industry, textile products and derivatives, and besides that there is also a food industry. These industries are included in the classification of large industry, medium industry, small industry and home industry.
The area of east Ungaran sub-district is around 3,799 square kilometers or 3.99 percent of the total area of Semarang Regency. Mostly for the use of agricultural land, both rice farming and non-rice farming. Agricultural land is mostly used for non-rice land use, and non-agricultural land is mostly used for houses and buildings.

In East Ungaran Sub-district, the village that has the most extensive rice fields is Mluweh Village, the most extensive use of agricultural land is not in Kalikayen Village, and the most extensive use of land for houses and buildings in Kawengen Village. Mluweh Village is located in a relatively low-lying area, so it has more water sources. Kawengen Village, one of the villages on the border between Semarang Regency and Demak Regency, is crossed by a village highway, making it a choice of residence, easy access to everywhere, even though 30 years ago it was one of the most disadvantaged areas. The characteristics of industrial areas can be assessed from the location and accessibility of the area, land use, and physial condition of the region. Industrial need access roads so that the are easily accsessible in meeting the needs of row material and marketing their product. Land use in the area can be used to make development to plans and supporting facilities. Industry located in a residential area are difficult to develop, because land is limited, and in general the requirement for esthablishing an industry on infertile land, and not the middle of dense setlements.

\subsection{Condition of the Population}

Population is the most important human resource in the development process. Population at working age becomes laborers in industrial processes. The conditions of the population in the villages around the industrial location are varied and dynamic. Population density is the ratio between population and area. The area of the village remained relatively unchanged, while the number of inhabitants changed every year, so the population density became dynamic. Population density is low or less than 1000 people / square kilometers, only in two villages, namely Kawengen Village and Mluweh Village. Kawengen Village is at the very end of the border with Demak Regency and Semarang City, as well as Mluweh Village. The highest population density is Gedanganak Village.

The population that continues to grow can be known from the population growth rate. Population growth in villages around industrial locations varies, from the lowest growth rate in Gedanganak Village to minus 1.1 percent and the highest population growth rate in Kalongan Village at 5.99 percent. Eight other villages with population growth rates between the two villages. 
The average millenal population in each village is approximately 30 percent of the total population in each village. The highest number of millennials is in Mluweh Village and the least in Leyangan Village. Millennials are people who were born in the period
1980 - 2000, so that at this time they are aged between 19-39 years or 20-30 years. Millennial residents who live in villages around the industrial location become the next generation of rural development, so they do not have to migrate outside the village.

Table 1. Population Dynamics in Eastern Ungaran Sub-District

\begin{tabular}{llll}
\hline Rural & MILLENIAL & POPULATION & $\begin{array}{l}\text { POPULATION } \\
\text { GROWTH }\end{array}$ \\
\hline BEJI & 32,92 & 3.919 & $-0,51$ \\
LEYANATION & 3.904 & 1,51 \\
KALONGAN & 29,09 & 1.377 & 5,99 \\
KAWENGEN & 31,08 & 932 & 3,56 \\
KALIKAYEN & 35,15 & 1.157 & 1,37 \\
MLUWEH & 34,41 & 987 & 1,80 \\
SUSUKAN & 29,95 & 3.069 & 1,53 \\
KALIREJO & 30,21 & 1.414 & 2,36 \\
SIDOMULYO & 29,23 & 3.609 & 1,65 \\
GEDANGANAK & 31,40 & 4.520 & $-1,71$ \\
\hline
\end{tabular}

\section{Source:}

The villages around the industrial location have relatively more population. Gedanganak Village has the highest population density, because it is an industrial location. Most of the workers who work in the industrial sector come from outside the village, and they do not have a house, but some are boarding houses, boarding houses, and ngalju. Those who live in boarding houses and boarding houses reside in villages around the industry, and some are married to residents as precisely as they become migrants. Kawengen and Kalongan villages have a very high population growth rate, this can be attributed to the accessibility, location and area of the village, making it a choice for residence. In these villages there are a number of new housing estates that offer housing.

Increasing number of population with increasing population density and population growth has not been followed by high quality. The quality of the population can be analyzed from the level of education of the population. Most of the population is still educated elementary (Elementary School and
Middle School), namely in the Village of Mluweh. The villages of Kawengen and Kalikayen are dominated by people of low quality. Sidomulto Village, is one of the villages that has better quality, with a population of more than tertiary education, reaching 31.17 percent.

\subsection{Employment Structure}

The occupational structure of the population in villages around the industry varies, with a combination of employment in the agricultural or primary sector, the industrial or secondary sector, and the service or tertiary sector. Employment employment in the dominant agricultural sector is in Kawengen Village, which is equal to 50.70 percent, and at least in Gedanganak Village (2.9 percent). Whereas employment opportunities for the population in the industrial sector were mostly in Mluweh Village, which was 64.34 percent. The most jobs in the service sector are in Susukan Village, which is 61.69 percent.

Table 2. Employment Structure in the East Ungaran Sub-District

\begin{tabular}{lccc}
\hline Rural & $\begin{array}{c}\text { AGRICULTURAL } \\
\text { SECTOR }\end{array}$ & $\begin{array}{c}\text { INDUSTRY } \\
\text { MANUFACTURE }\end{array}$ & SERVICE \\
\hline BEJI & 6,68 & 45,25 & 48,07 \\
LEYANGAN & 8,78 & 42,94 & 48,19 \\
KALONGAN & 24,29 & 50,65 & 24,97 \\
KAWENGEN & 50,70 & 30,52 & 18,78 \\
KALIKAYEN & 18,65 & 57,66 & 23,69 \\
MLUWEH & 26,49 & 64,20 & 9,31 \\
SUSUKAN & 7,92 & 30,39 & 61,69 \\
KALIREJO & 11,12 & 48,93 & 39,86 \\
SIDOMULYO & 5,23 & 26,26 & 68.51 \\
GEDANGANAK & 2,97 & 48,23 & 48,80 \\
\hline
\end{tabular}


Villages with wider use of agricultural land are not always followed by employment in the agricultural sector. The highest land use for agriculture is 76 percent in Mluweh Village, but in Mluweh Village the population that has a dominant employment (64.34 percent) is in the industrial sector or the secondary sector. In some villages with more extensive agricultural land use, the population is less interested in working in the agriculture sector. The villages around the industry do not always work in the industrial sector, because to become industrial workers has special requirements, at least the level of formal education they have and the special skills required.

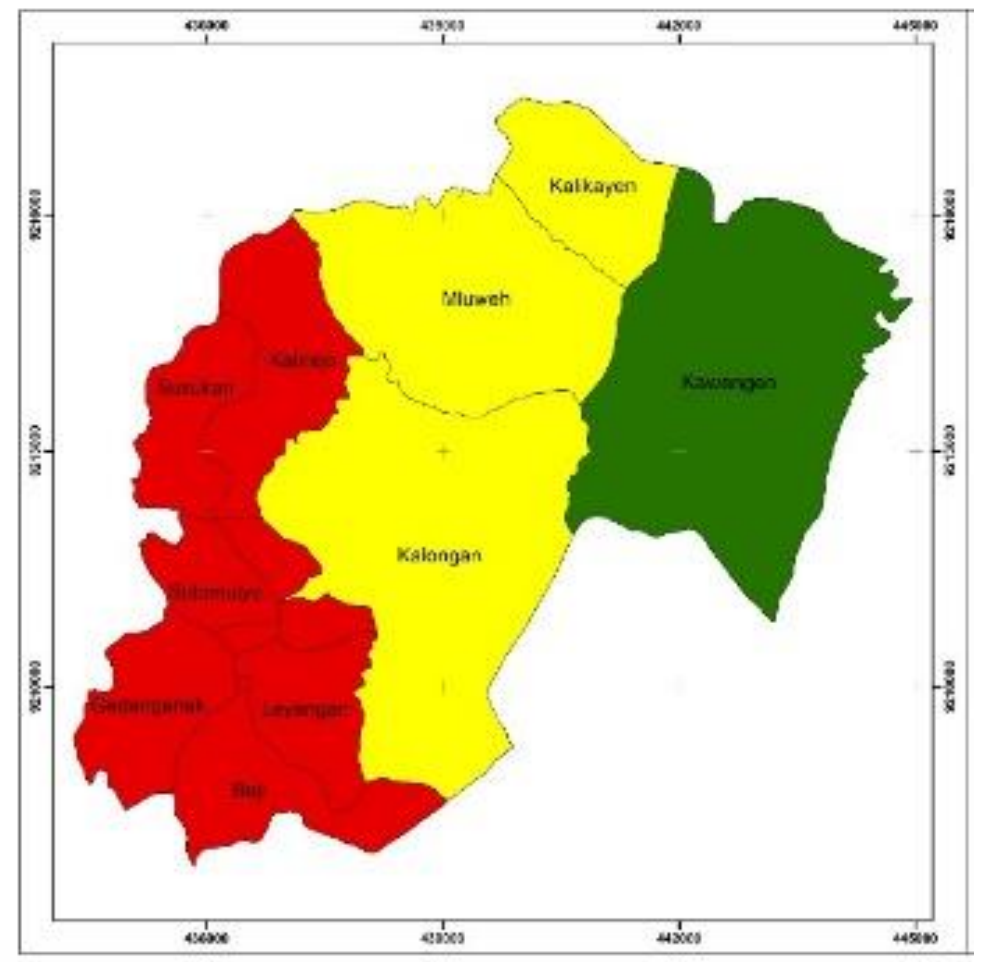

Figure 1. Map of the Distribution of Non-Agricultural Work Structures in Eastern Ungaran Sub-District

The structure of non-agricultural work is divided into three classes, namely high class ( $>65$ percent), middle class (33- $<65$ percent), and low class $(<35$ percent). The most dominant non-agricultural employment opportunities are in Beji Village, Leyangan Village, Gedanganak Village, Sidomulyo Village, Susukan Village, and Kalirejo Village. Gedanganak Village has the highest employment structure in the non-agricultural sector, while Kawengen Village has the lowest non-agricultural employment structure. This situation is in accordance with the conditions in other regions, that with the presence of industry can shift the structure of the employment of residents [18], and the contribution of employment in the agricultural sector is very low compared to the manufacturing industry sector [19]. The structure of employment in this research area also occurs in other countries, namely in the Austrilia region, where there has been a change in the structure of employment since the 1990s [20]. This situation (the increase in non-agricultural employment) was supported by the success of infrastructure development and the emergence of population activity centers.

\section{CONCLUSION}

The villages around the industrial location have almost the same characteristics as the villages in general. Several villages have moderate regional accessibility, easily accessible from various directions, but are not yet equipped with public transportation. The condition of the population is owned with a moderate population density, although there are villages with a very high population growth rate (more than 5 percent per year). All villages around industrial sites have a millennial population of about one third of the total population, this is the concern of all parties in the context of developing villages around the industry. The quality of human resources that is still low is still found in villages around industrial locations. The main employment structure is dominated by the nonagricultural sector. In the majority of villages (not all) 
around industrial locations, residents have jobs in the manufacturing indsutry and service sector.

\section{REFERENCES}

[1] Astuti, P., Nur Hanifah JS, Aulia Nur Aziza, Nur Fadilah Alwan, Fahira: Overview of Knowledge and Attitudes of Hasanudin University Students Regarding the Realization of Sustainable Development Goals 2030 in Indonesia. Journal ABDI. Vol. 2, No. 1, Januari 2020. pp. 40-47 (2020).

[2] RRW, Edy Prihantoro : Development Communication Strategy by Bojonegoro Goverment on Applying Nawacita and Sustainable Develompment Goals. Journal Komunitas Pembangunan. Vol.18 (02), pp. 117129 (2020).

[3] International Training Center (ITC). Sustainable Development Goals. Worker's Reference manual for Agendan Sustainable Development 2030. ITC ILO. ACTRAV Bureau for Workers Activity (2018).

[4] Population Reference Bureau. World Population Data Sheet. USAID. Washington, DC. USA.www.prb.org (2015).

[5] United Stated. World Pupulation Prospect 2019 Hoghtlight. Department of Economic and Social affair. Population Division. New York. United Nation. (2019).

[6] International Labour Organisation. World Employment Social Outlook: Trend 2019. Geneva: ILO. (2019).

[7] International Labour Organisation. ILO Monitoring 2nd edition: COVID-19 and the World of Work. Latest Estiami and Analysis. ILO. (2020).

[8] Central Bureau of Statistic. Profile of Indonesian Population Results of SUPAS 2015. Jakarta. Central Bureau of Statistic. (2016).

[9] Central Bureau of Statistic. Laborer Situation in Indonesia February 2020. Jakarta. Central Bureau of Statistic. (2020).

[10] Todaro, M.P., Smith, S.C. Economic Development. Jakarta. Erlangga.(2014).
[11] Simanjorang, W. E. Regional Development: Case Study Perspective of Kuala Tanjung Industrial Estate. Jakarta. Universitas Indonesia. (2010).

[12] Siska. The Impact of the Coal Industry on Social Economy of Communities Around Jembayan Village, Loa District, Kutai Kertanegara Regency. eJournal Administrasi Negara 1(2):473-493. (2013).

[13] Hakim, A.R. Changes in Economic Structures and Employment Opportunities in Indonesia (Input Output Analysis). Proceedings of the National Conference on Mathematical Research and Learning II (KNPMP II) 58-66.

[14] Anonim. Law of the Republic of Indonesia Noor 3 of 2014 concerning Industry. http://www.bpkp.go.id.

[15] Rahmawati, F. Dan Jawoto Sih Setyono. Development of Rural Industries and Changes in the Characteristics of Village Areas in Nguwet Village, Kranggan District, Temanggung Regency. Journal of Engineering - PWK. Vol. 3. Number 4 pp. 792-806. (2014).

[16] Anonim. Regulation of the Minister of Industry Number 35 Year 2010 Concerning Technical Guidelines for the Development of Industrial Estates. http://www/bkpm.kemenperin.go.id

[17] Dirdjojuwono, R.W. Indonesian Industrial EstateConcept Planning and Its Application. Bogor. Young entrepreneurs.

[18] Nuraeni, Y. Nuraeni, Y. The Impact of the Development of the Nickel Mining Industry on Social, Economic and Cultural Conditions of the Community. Edusaintek National Seminar Articles. FMIPA UNIMUS 2018. ISBN:978-6025614-35-4.pp. 12-22. (2018).

[19] Parmadi, Purwoko Hari Prihanto, Rts. Ratnawati. City Economic Growth and Its Influence on Job Opportunities in the City of Jambi. Jurnal Paradigma Ekonomika. Vol. 15. No. 1, JanuariJuni. Pp. 85-94. (2020).

[20] Garnett, AM, \& Lewis PE. 2007. Population and Employment Changes in Regional Australia. http://doi.org/10.111/j.1759-3441.2007.tb00425. 